\title{
システム天井用吹出口の CFD モデリング手法としての P.V.法とその応用 P.V. METHOD AS CFD MODELING OF SYSTEM CEILING AIR DIFFUSER AND ITS APPLICATION
}

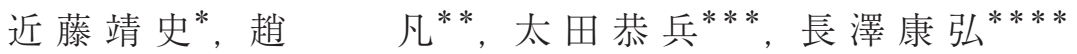 \\ Yasushi KONDO, Fan ZHAO, Kyohei OTA \\ and Yasuhiro NAGASAWA
}

\begin{abstract}
The previous studies show that the prescribed velocity method (hereafter, P. V. method) is effective to simulate complicated airflow from an air diffuser in CFD. However P.V. method is not applied to system ceiling air diffusers which are popular in office buildings. In this paper, the unstructured fine mesh CFD is conducted to obtain the airflow data of four types of system ceiling diffuser. Then the airflow data is applied in the structured coarse mesh CFD and the short circuit rate and the normalized concentration of occupied zone are examined as ventilation effectiveness. The relationship between shape of diffuser and ventilation effectiveness is discussed on the basis of CFD results.
\end{abstract}

Keywords: Computational Fluid Dynamics, Prescribed Velocity Method, System Ceiling Air Diffuser, Short Circuit, Normalized Concentration of Occupied Zone

CFD 解析，P.V.法，システム天井用吹出口，ショートサーキット，規準化居住域濃度

\section{1. はじめに}

室内の気流場を特徵づける最も重要な要因の一つとして、吹出気 流性状が挙げられる。特に、省エネルギーと快適性・健康性の維持 の観点から、換気・空調用の吹出口からの気流により、効率よく居 住域に新鮮外気を供給し、居住域の温熱環境を快適範囲に維持する ことが重要である。一方、近年のオフィス空間ではデザイン性やコ ストなどの観点からシステム天井が採用されることが多い。システ ム天井に用いられる吹出口(以降、システム天井用吹出口と記す)に は多くの種類があるにもかかわらず、これらの吹出気流性状につい ての研究はほとんどなされていない。これに対し、既往の研究 1) 3) ではオフィスビル等で用いられる複雑な形状の空調用吹出口を対象 に、数值流体解析 (Computational Fluid Dynamics、以降 CFD 解 析と記す)における吹出口のモデリング手法として P.V. 法 (Prescribed Velocity Method)が有効であることが示されている。

本研究では、4 種類のシステム天井用吹出口形状を詳細に非構造 格子系 CFD 解析により再現し、吹出気流データを作成する。また、 実験を行い、非構造格子系 CFD 解析結果の妥当性を確認する。さ らに吹出気流データを P.V.法に適用し、構造格子系 CFD 解析を行 う。その際、風速規定面での乱流統計量 $(\mathrm{k}$ と $\varepsilon$ )の規定の必要性を 検討した。次に、P.V.法の適用例として空調気流のショートサーキ ットを検討する。吹出口、照明とスリット型吸込口がひとつのパネ ルに組み込まれたグリッド型システム天井を対象にして、解析結果
からショートサーキット率 4),5)や規準化居住域濃度 6)等を検討寸る。

\section{2. 非構造格子系 CFD 解析による吹出気流データの作成 2.1 解析概要}

解析対象空間を図 1 に示す。解析対象空間は吹出口用チャンバの 一部を含めた空間である。解析条件を表 1 注1) に示す。天井の中央に 1 つの吹出口を設置した状態を想定し、空間の対称性から空間全体 の $1 / 4$ 領域 $(2.8 \mathrm{~m}(\mathrm{X}) \times 2.8 \mathrm{~m}(\mathrm{Y}) \times 2.86 \mathrm{~m}(\mathrm{Z})$ 、吹出口用チャンバを含む $)$ について解析寸る。既往の研究 1) 3) から吹出口チャンバへのダクト 接続の位置が吹出気流の分布に影響を与えると考え、特に吹出気流 の非対称性を無くすために、本研究では吹出口用チャンバの側面に 一様な風速(吹出風量は $35 \mathrm{~m}^{3} / \mathrm{h}$ )を与えた。乱流モデルは低 $\operatorname{Re}$ 数型 $\mathrm{k}-\varepsilon$ model (Abe-Nagano-Kondo) 7)を用いる。壁面の壁座標 $\mathrm{y}^{+}$は概ね 1 以下となるように要素を分割した。また、温度分布が吹出気流に 影響のない等温場として解析を行う。

\section{2 解析ケース}

解析ケースと解析モデルを表 2 に示す。本研究では、角型多層コ ーン型吹出口( $\mathrm{K}$ 社製。以降、アネモ型吹出口と記す)、吹出気流が斜 め 4 方向となる吹出口 2 種類 ( $\mathrm{K}$ 社製。以降、 4 方向吹出口-350 と 4 方向吹出口-240 と記す) と吹出気流が 2 方向となる吹出口( $\mathrm{K}$ 社製。 以降、2 方向吹出口と記す)の計 4 種類の吹出口を再現し、解析を行 う。表 2 中の矢印に示すように吹出気流が形成されると想定される。
* 東京都市大学工学部 教授·博士 (工学)

** 高砂熱学 修士 (工学) (研究当時 東京都市大学大学院 博十前期浬程)

*** 東京都市大学大学院 博士後期課程 - 修士 (工学)

**** 鹿児島大学大学院理工学研究科 助教 $\cdot$ 博士 (工学)
Prof., Faculty of Engineering, Tokyo City University, Dr. Eng.

Takasago Thermal Engineering Co., Ltd., M. Eng.

(Former Graduate Student, Tokyo City University)

Graduate Student of Doctor Course, Tokyo City University, M. Eng.

Assistant Prof., Graduate School of Science and Engineering, Kagoshima University, Dr. Eng. 


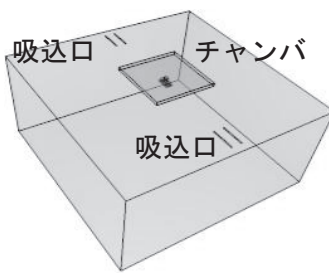

(a) 鳥瞰図 (全体)

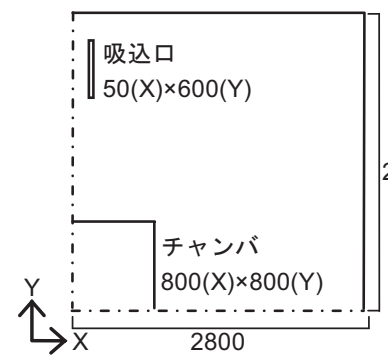

(c) 平面図 $(1 / 4$ 領域)

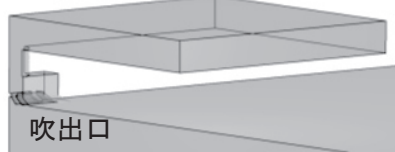

(b) 鳥瞰図

(吹出口・チャンバ、 $1 / 4$ 領域)

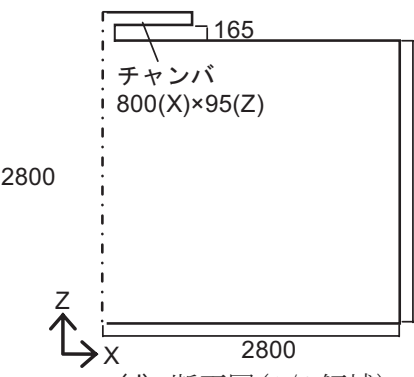

表 1 解析条件 (非構造格子系 CFD 解析)

\begin{tabular}{|c|c|}
\hline 解析領域 & $\begin{array}{l}5.6 \mathrm{~m}(\mathrm{X}) \times 5.6 \mathrm{~m}(\mathrm{Y}) \times 2.86 \mathrm{~m}(\mathrm{Z})(\text { 吹出口用チャンバを含 } \\
\text { む)、天井高さは } 2.6 \mathrm{~m} \text { 、対称性から全体の } 1 / 4 \text { 領域。 }\end{array}$ \\
\hline 要素分割数 & 約 300 万要素 \\
\hline 温度条件 & なし(等温度場を想定) \\
\hline $\begin{array}{l}\text { 移流項 } \\
\text { スキーム }\end{array}$ & MUSCL (2 次精度) \\
\hline 乱流モデル & 低 Reynolds 数型 k- $\varepsilon$ model (Abe-Nagano-Kondo) \\
\hline 壁面条件 & 天井・床：no-slip 条件、壁面(対称面)：free-slip 条件 \\
\hline $\begin{array}{l}\text { 流入条件 } \\
\text { (1/4 領域) }\end{array}$ & $\begin{array}{l}\left.Q_{\mathrm{in}}=35 \mathrm{~m}^{3} / \mathrm{h} \quad \text { (吹出口 } 1 \text { 個の風量の } 1 / 4\right) \text { 吹出口用チ } \\
\text { ヤンバの側面に一様に風速を与える。 } \\
k_{\mathrm{in}}=0.12 \mathrm{~m}^{2} / \mathrm{s}^{2} 、 \varepsilon_{\mathrm{in}}=0.08 \mathrm{~m}^{2} / \mathrm{s}^{3} \text { 注 } 1 \text { ) }\end{array}$ \\
\hline $\begin{array}{l}\text { 流出条件 } \\
\text { (1/4 領域) }\end{array}$ & $\begin{array}{l}\text { 表面圧力規定(吸込口において } 0 \mathrm{~Pa}) \\
\text { 天井スリット部分: } 0.05 \mathrm{~m} \times 0.6 \mathrm{~m}(1 \text { ヶ所) }\end{array}$ \\
\hline
\end{tabular}

図 1 解析モデル(非構造格子系 $\mathrm{CFD}$ 解析) 単位 $[\mathrm{mm}]$

表 2 解析ケースと解析モデル (非構造格子系 CFD 解析)

\begin{tabular}{|c|c|c|c|c|}
\hline ケース名 & (a) アネモ型吹出口 & (b) 4 方向吹出口-350 & (c) 4 方向吹出口-240 & (d) 2 方向吹出口 \\
\hline \multicolumn{5}{|l|}{ 写真 } \\
\hline \multicolumn{5}{|l|}{ CFD 解析 } \\
\hline サイズ & $350 \mathrm{~mm}(\mathrm{X}) \times 210 \mathrm{~mm}(\mathrm{Y})$ & $350 \mathrm{~mm}(\mathrm{X}) \times 240 \mathrm{~mm}(\mathrm{Y})$ & $240 \mathrm{~mm}(\mathrm{X}) \times 240 \mathrm{~mm}(\mathrm{Y})$ & $240 \mathrm{~mm}(\mathrm{X}) \times 240 \mathrm{~mm}(\mathrm{Y})$ \\
\hline
\end{tabular}

表 3 吹出口のベーンの角度 (天井面に対する角度) と吹出気流の水平方向の幅

\begin{tabular}{|c|c|c|c|c|c|c|}
\hline & & \multicolumn{4}{|c|}{ 吹出口のベーンの角度 (天井面に対する角度) } & \multirow{2}{*}{ 吹出気流の水平方向の幅 } \\
\hline & & 1 枚目(内側) & 2 枚目 & 3 枚目 & 4 枚目(外側) & \\
\hline (a) & アネモ型吹出口 & $37^{\circ}$ & $40^{\circ}$ & - & - & $\fallingdotseq$ 吹出口の長辺＋短辺 \\
\hline (b) & 4 方向吹出口 - 350 & $22^{\circ}$ & $15^{\circ}$ & $15^{\circ}$ & $17^{\circ}$ & $\fallingdotseq$ 吹出口の長辺 $\div 2$ \\
\hline (c) & 4 方向吹出口 - 240 & $34^{\circ}$ & $34^{\circ}$ & $27^{\circ}$ & $27^{\circ}$ & 吹出気流は隅角部に集中し、幅は狭い。 \\
\hline (d) & 2 方向吹出口 & $22^{\circ}$ & $19^{\circ}$ & $27^{\circ}$ & - & $\doteqdot$ 吹出口の 1 辺 \\
\hline
\end{tabular}

\section{3 解析結果}

非構造格子系 CFD 解析の結果を図 2 に示寸。ケース (a)、(b) と (d) は天井に沿った水平方向の天井付着噴流が形成されている。アネモ 型吹出口では、短辺 $(\mathrm{Y}) よ り$ 長辺 $(\mathrm{X})$ のほうが風速は大きく、吹出風 量が多い。4 方向吹出口-350 では、吹出気流がほぼ X=Y ラインに 沿って形成されている。一方、4 方向吹出口-240では、天井付着噴 流が形成されておらず、斜め下方に向かう吹出気流が形成されてい る。2 方向吹出口では、吹出口形状からわかるように長辺方向 $(\mathrm{X})$ に吹出気流が形成されている。なお、このような気流の形成は可視 化実験により確認している。

ケース $(a) 、(b) 、(d)$ で天井付着噴流が形成され、ケース $(c)$ で形成
されない理由を以下に考察する。吹出気流が天井に付着するから゙う かは下記の 2 点が関わると考えられる。

(1)吹出口のベーンの角度

(2)吹出気流の水平方向の幅

表 3 に各ケースでの吹出口のベーンの角度と吹出気流の水平方向 の幅を示す。アネモ型吹出口では吹出気流の水平方向の幅が広く、 ベーンの角度も $40^{\circ}$ 以下であり、天井付着噴流が形成されたと考え られる。2 方向吹出口では吹出気流の幅は比較的狭いが、ベーンの 角度が小さく、天井付着噴流が形成された。一方、4 方向吹出口 240 では吹出気流は隅角部に集中し、水平方向の幅が狭く、ベーン の角度も大きめであったため、天井付着噴流は形成されなかったと 


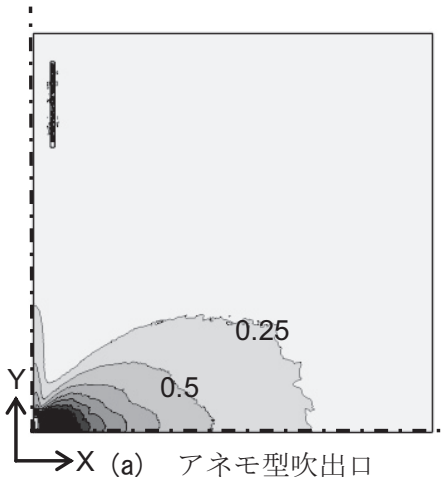

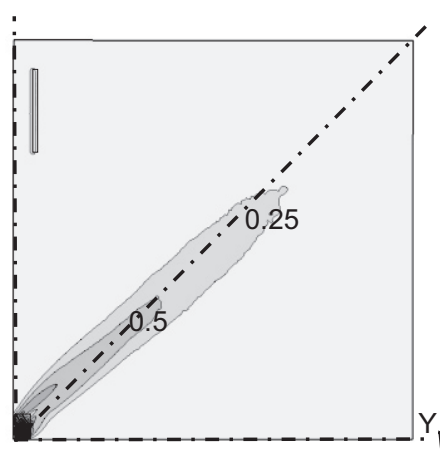

(b) 4 方向吹出口-350

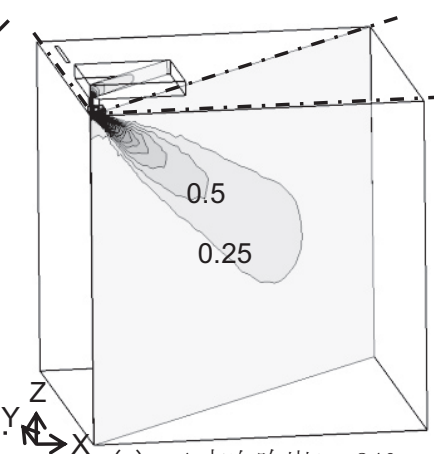

(c) 4 方向吹出口-240

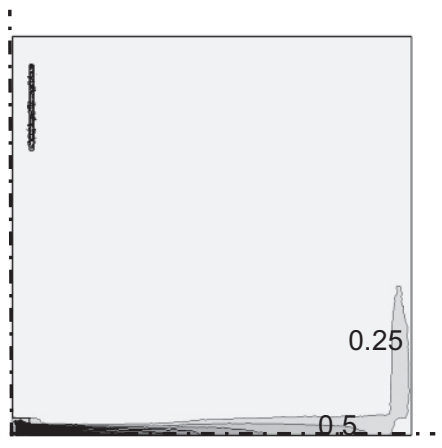

(d) 2 方向吹出口

（1） スカラー風速 $[\mathrm{m} / \mathrm{s}] （ （ \mathrm{a}) 、(\mathrm{~b}) 、(\mathrm{~d})$ は天井から $10 \mathrm{~mm}$ 下の水平断面 (c) は $\mathrm{X}=\mathrm{Y}$ の鉛直断面)

$0.0 \mathrm{~m} / \mathrm{s}$

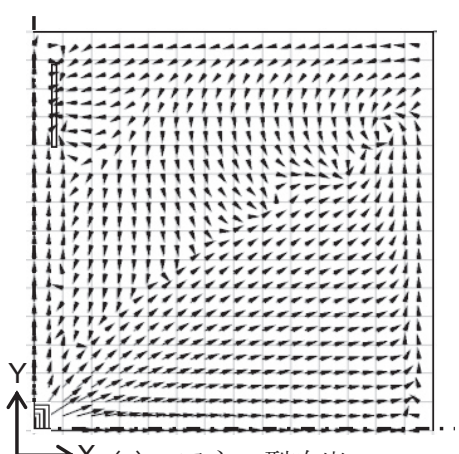

(a) アネモ型吹出口

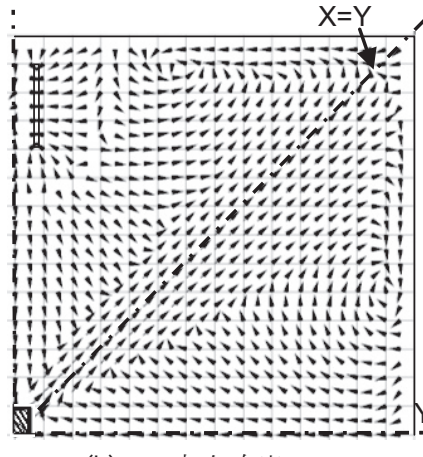

(b) 4 方向吹出口-350

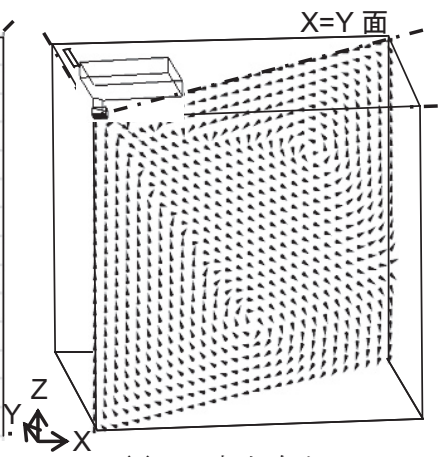

(c) 4 方向吹出口-240

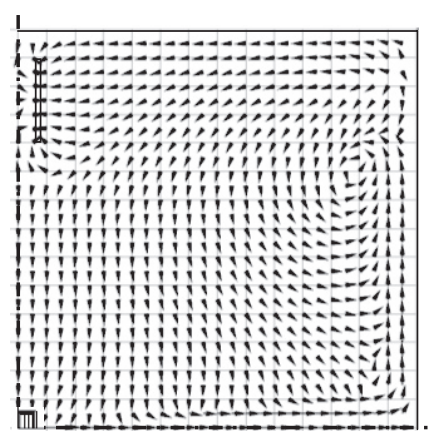

(d) 2 方向吹出口

（2）ベクトル分布 ( (a)、（b)、（d）は天井から $10 \mathrm{~mm}$ 下の水平断面 (c) は X=Y の鉛直断面）

図 2 非構造格子系 CFD 解析の結果

吸込口 $(700(\mathrm{~W}) \times 300(\mathrm{D}), \mathrm{FL}+0 \sim 900)$

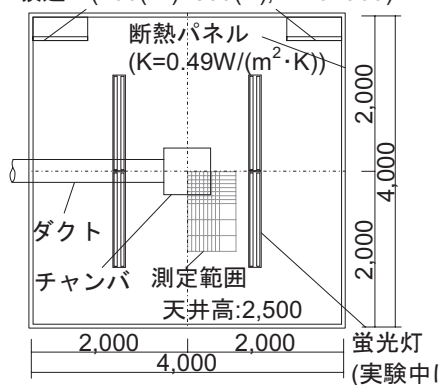

(a) 平面図

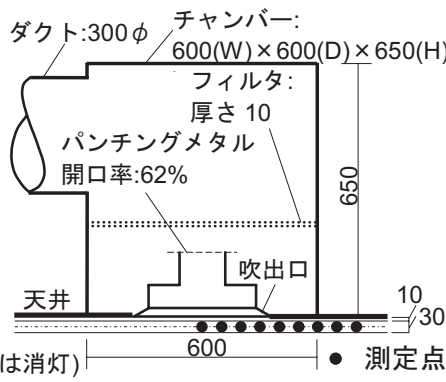

(b) 吹出口 断面図

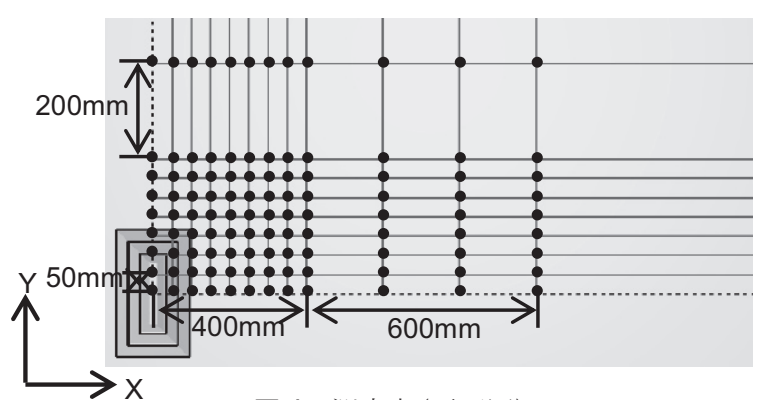

図 4 測定点(平面図)

表 4 測定機器

\begin{tabular}{l|l}
\hline \multicolumn{1}{c|}{ 測定機器 } & \multicolumn{1}{c}{ 備考 } \\
\hline 3 次元超音波風速計 DT-700 & ソニック社製 \\
\hline トラバース装置 MT-3000 TYPE 3S & 日東紡音響社製 \\
\hline $\mathrm{T}$ 型熱電対 & 江藤電気 \\
\hline
\end{tabular}

考えられる。これに対し、4 方向吹出口 - 350 では吹出気流の幅は 吹出口長辺の 2 分の 1 程度であり、ベーンの角度も最も小さいため、 天井付着噴流が形成されたと考えられる。

\section{3. 実験による非構造格子系 CFD 解析結果の確認 \\ 3.1 実験概要}

実験室を図 3 に示す。等温場に設定した実験室を対象として吹出 口周辺の気流分布を測定する。代表としてアネモ型吹出口(表 2 (a)) を用いて実験を行う。実験により得られた吹出口周辺の吹出気流デ ータを非構造格子系 CFD 解析から得られた吹出気流データと比較 し、非構造格子系 CFD 解析結果の妥当性を確認寸る。

\section{2 実験条件}

一つのアネモ型吹出口を天井に設置した環境実験室 $(4.0 \mathrm{~m} \times 4.0 \mathrm{~m} \times 2.5 \mathrm{~m})$ において、吹出口周辺を測定対象として測定す る。測定領域および測定点を図 4 に示寸。天井面下の X-Y 断面(図 4 (a))では、X 方向に吹出口中央から $400 \mathrm{~mm}$ まで $50 \mathrm{~mm}$ 間隔で計 9 点と $400 \mathrm{~mm}$ から $1000 \mathrm{~mm}$ まで $200 \mathrm{~mm}$ 間隔で計 3 点を測定する。 Y 方向も同様である。高さ方向は天井面から下 $10 \mathrm{~mm}$ から $40 \mathrm{~mm}$ までの領域において風速測定を行う。吹出風量は $300 \mathrm{~m}^{3} / \mathrm{h}$ に調整す る。

\section{3 測定機器}

測定機器を表 4 に示す。 3 次元超音波風速計を使用し、吹出口周 辺の気流分布を詳細に測定する。3 次元風速計は $50 \mathrm{~Hz}$ で 10 秒間の 計測を行う。本実験ではトラバース装置を用いて測定を行う。また、 等温場であることを $\mathrm{T}$ 型熱電対により吹出温度および室内空気温度 数点の測定結果から確認した。 


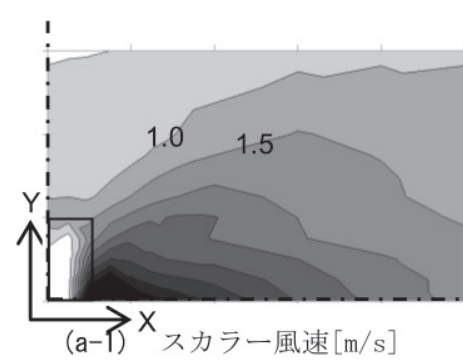

(a) 実験結果

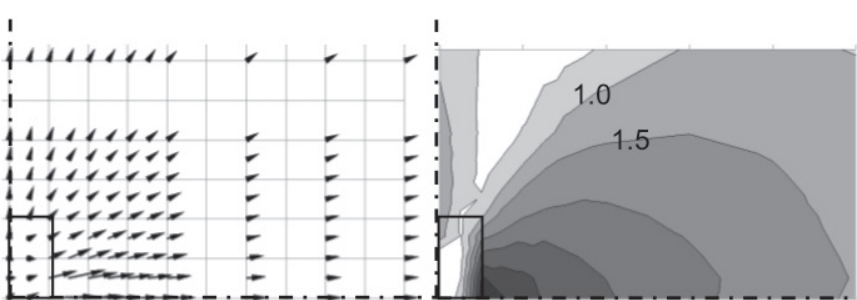

(b-1) スカラー風速 $[\mathrm{m} / \mathrm{s}]$

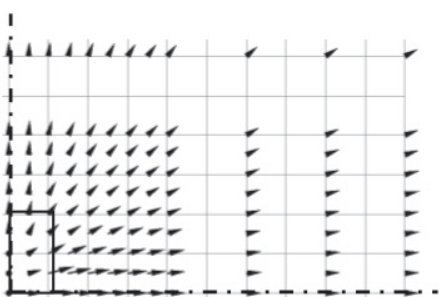

(b-2) ベクトル分布

$0.0 \mathrm{~m} / \mathrm{s}$

$5.0 \mathrm{~m} / \mathrm{s}$

(b) 非構造格子系 CFD 解析結果

図 5 実験結果と非構造格子系 CFD 解析結果の比較

表 5 解析条件 (構造格子系 CFD 解析、等温)

\begin{tabular}{|c|c|c|c|c|}
\hline 解析領域 & \multicolumn{4}{|c|}{$5.6 \mathrm{~m}(\mathrm{X}) \times 5.6 \mathrm{~m}(\mathrm{Y}) \times 2.8 \mathrm{~m}(\mathrm{Z})$ 対称性から全体の $1 / 4$ 領域 } \\
\hline 要素分割数 & \multicolumn{4}{|l|}{$70(\mathrm{X}) \times 70(\mathrm{Y}) \times 84(\mathrm{Z})=411600$} \\
\hline 温度条件 & \multicolumn{4}{|l|}{ なし(等温度場を想定) } \\
\hline 乱流モデル & \multicolumn{4}{|l|}{ 標準 k`₹ model } \\
\hline 移流項 & \multicolumn{4}{|l|}{ QUICK } \\
\hline 吹出モデル & \multicolumn{4}{|c|}{ 各吹出口を想定し P.V.法に適用 } \\
\hline 壁面条件 & \multicolumn{4}{|c|}{ 天井-床：一般化対数則、鉛直面(対称面) : free-slip 条件 } \\
\hline \multirow{4}{*}{$\begin{array}{l}\text { 流入条件 } \\
\text { (1/4 領域) }\end{array}$} & (a) アネモ型吹出口 & (b) 4 方向吹出口 -350 & (c) 4 方向吹出口 -240 & (d) 2 方向吹出口 \\
\hline & $U_{i n}=0.61 \mathrm{~m} / \mathrm{s}\left(Q_{i n}=35 \mathrm{~m}^{3} / \mathrm{h}\right)$ & $U_{i n}=0.53 \mathrm{~m} / \mathrm{s}\left(Q_{i n}=35 \mathrm{~m}^{3} / \mathrm{h}\right)$ & $U_{\text {in }}=0.67 \mathrm{~m} / \mathrm{s}\left(Q_{i n}=35 \mathrm{~m}^{3} / \mathrm{h}\right)$ & $U_{\text {in }}=0.67 \mathrm{~m} / \mathrm{s}\left(Q_{i n}=35 \mathrm{~m}^{3} / \mathrm{h}\right)$ \\
\hline & $k_{i n}=3.8 \times 10^{-3} \mathrm{~m}^{2} / \mathrm{s}^{2}$ & $k_{i n}=2.8 \times 10^{-3} \mathrm{~m}^{2} / \mathrm{s}^{2}$ & $k_{i n}=4.5 \times 10^{-3} \mathrm{~m}^{2} / \mathrm{s}^{2}$ & $k_{i n}=4.5 \times 10^{-3} \mathrm{~m}^{2} / \mathrm{s}^{2}$ \\
\hline & $\varepsilon_{i n}=7.6 \times 10^{-4} \mathrm{~m}^{2} / \mathrm{s}^{3}$ & $\varepsilon_{i n}=4.9 \times 10^{-4} \mathrm{~m}^{2} / \mathrm{s}^{3}$ & $\varepsilon_{i n}=9.8 \times 10^{-4} \mathrm{~m}^{2} / \mathrm{s}^{3}$ & $\varepsilon_{i n}=9.8 \times 10^{-4} \mathrm{~m}^{2} / \mathrm{s}^{3}$ \\
\hline 流出条件 & \multicolumn{4}{|l|}{$U_{\text {out }}=0.54 \mathrm{~m} / \mathrm{s}\left(Q_{\text {out }}=35 \mathrm{~m}^{3} / \mathrm{h}\right)$} \\
\hline
\end{tabular}

表 6 P. V. 法の規定面 $(1 / 4$ 領域 $)$

\begin{tabular}{l|c|c|c|c|c}
\hline ケース名 & (a) アネモ型吹出口 & (b) 4 方向吹出口-350 & (c) 4 方向吹出口-240 & $(\mathrm{d})$ & 2 方向吹出口 \\
\hline 流入境界面サイズ & $105 \mathrm{~mm}(\mathrm{X}) \times 175 \mathrm{~mm}(\mathrm{Y})$ & $120 \mathrm{~mm}(\mathrm{X}) \times 175 \mathrm{~mm}(\mathrm{Y})$ & $120 \mathrm{~mm}(\mathrm{X}) \times 120 \mathrm{~mm}(\mathrm{Y})$ & $120 \mathrm{~mm}(\mathrm{X}) \times 120 \mathrm{~mm}(\mathrm{Y})$ \\
\hline 仮想ボックスサイズ & $130 \mathrm{~mm}(\mathrm{X}) \times 200 \mathrm{~mm}(\mathrm{Y})$ & $145 \mathrm{~mm}(\mathrm{X}) \times 200 \mathrm{~mm}(\mathrm{Y})$ & $150 \mathrm{~mm}(\mathrm{X}) \times 150 \mathrm{~mm}(\mathrm{Y})$ 注 3$)$ & $155 \mathrm{~mm}(\mathrm{X}) \times 155 \mathrm{~mm}(\mathrm{Y})$ \\
\hline
\end{tabular}

\section{4 非構造格子系 CFD 解析}

実験では吹出風量は $300 \mathrm{~m}^{3} / \mathrm{h}$ であるため、風量を実験と合わせた 条件で非構造格子系 CFD 解析を行い、これと比較した。風量以外 の条件は表 1 の解析条件と同じである。また、3 次元超音波風速計 で測定した実験結果と比較する非構造格子系 CFD 解析結果は、天 井面下 $10 \mathrm{~mm}$ から $40 \mathrm{~mm}$ の平均した風速である注2)。

\section{5 実験結果}

実験結果と非構造格子系 CFD 解析結果を図 5 に示す。実験結果 と非構造格子系 CFD 解析結果は概ね対応していることが確認でき る。しかし、吹出口中心付近では、非構造格子系 CFD 解析結果よ り実験結果の風速が大きい。この差異の原因として、吹出口上部の チャンバーのダクト接続位置が実験(図 3) と非構造格子系 CFD 解析 (図 1)で異なることが挙げられる。また、実験では吹出口の近くに照 明があり、これが短辺 $(\mathrm{Y})$ 方向の天井付着噴流の妨げとなっている可 能性がある。

\section{4. 構造格子系 CFD 解析における P.V.法の適用(等温) \\ 4.1 解析概要}

P.V.法とは吹出口を囲むように設定した仮想ボックス面に吹出気 流を規定して、複雑な吹出気流性状を再現する方法である。P.V.法

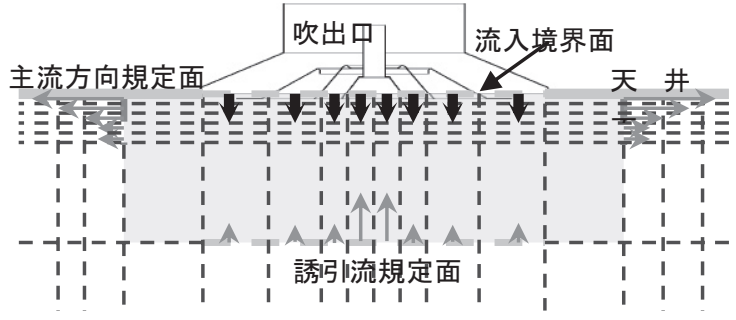

図 6 P. V. 法における風速規定面の概要

では、仮想ボックス面のうち吹出気流の風速が大きい領域に卓越す る風速成分を与える。図 6 に示寸ように主流方向風速成分、誘引流 成分を規定する。境界面には流入境界条件として、流入風速を一様 に規定する。

\subsection{P.V.法における吹出気流の規定方法}

P.V.法の規定方法 8)を表 6 と図 7 に示す。なお、吹出気流を規定 する位置は吹出気流にかかる浮力よりも吹出気流の慣性力が卓越す る位置とすることにより、非等温場における吹出気流データの汎用 性が高まる。本研究ではこれを考慮して、表 6 に示すような仮想ボ ックスのサイズを設定した。各ケースに非構造格子系 CFD 解析か ら得られた主流方向風速成分を主流方向規定面に規定し、接線方向 風速成分を接線方向規定面に規定寸る。各ケースに非構造格子系 
CFD 解析から得られた主流方向風速成分を主流方向規定面に規定 し、接線方向風速成分を接線方向規定面に規定する。また、ケース (c)では、吹出気流を再現するために、Z 方向吹出成分を Z 方向規定 面に規定寸る注 ${ }^{4)}$ 。流入条件は吹出口に規定し、非構造格子系 CFD 解析で得られた誘引流風速成分を誘引流規定面に規定寸る。ケース (a)、(b)と(d)は天井面から $50 \mathrm{~mm}$ 下部までの領域に吹出気流を規定 し、ケース(c)は天井面から $100 \mathrm{~mm}$ 下部までの領域に規定した。

\section{3 解析結果}

解析結果を図 8 に示す。非構造格子系 CFD 解析結果(図 2)と P.V. 法に適用した構造格子系 CFD 解析結果(図 8)は概ね対応しているこ とが確認できる。

\section{4 風速規定面での $\mathrm{k}$ と $\varepsilon$ の規定の必要性}

既往研究では、P.V.法を用いる構造格子系 CFD 解析における天井 付着噴流の減衰は非構造格子系 CFD 解析より小さく、拡散距離が 大きい(図 2 (a) と図 8 (a)を参照) との報告がある ${ }^{9}$ 。この原因のひと つとして、流入境界から吹き出された気流は規定面の近くで方向や 風速が大きく変化し、このため、乱流エネルギー $\mathrm{k}$ や渦動粘性係数 $v_{\mathrm{t}}$ が大きくなることが挙げられる。これを検討するため、非構造格 子系 CFD解析で得られた $\mathrm{k}$ と $を$ 構造格子系 CFD解析の風速規定 面に与えた場合と与えなかった場合を比較する。スカラー風速の解 析結果を図 9 に示す。結果からわかるように、風速規定面で $\mathrm{k}$ と を規定することによる影響はほとんど見られない。図 10 にとを の解析結果を比較する。吹出口付近では、 $\mathrm{k}$ とをを与えなかったケ ースより非構造格子系 CFD のほうが乱流エネルギーや渦動粘性係 数が小さい。また、 $\mathrm{k}$ とをを与えたケースは $\mathrm{k}$ とをを与えなかった

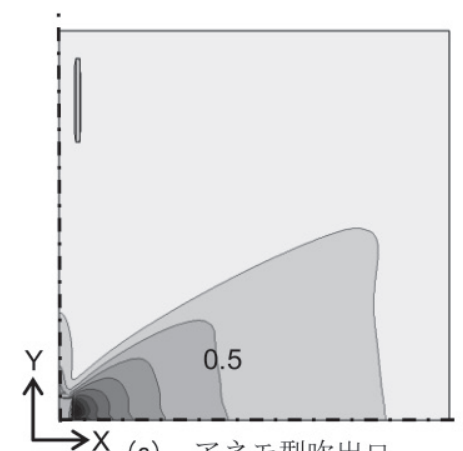

(a) アネモ型吹出口

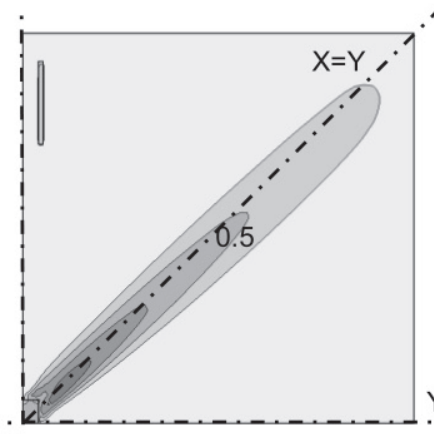

(b) 4 方向吹出口-350

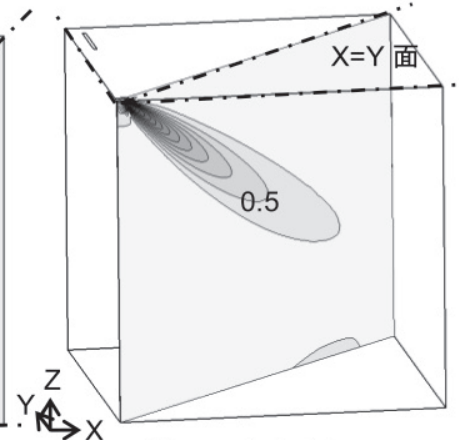

(c) 4 方向吹出口 -240

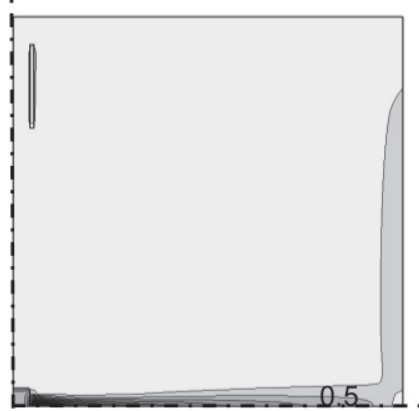

(d) 2 方向吹出口

（1） スカラー風速 $[\mathrm{m} / \mathrm{s}] （(\mathrm{a}) 、(\mathrm{~b}) 、(\mathrm{~d})$ は天井から $10 \mathrm{~mm}$ 下の水平断面 （c) は $\mathrm{X}=\mathrm{Y}$ の鉛直断面） $0.0 \mathrm{~m} / \mathrm{s} \quad 2.5 \mathrm{~m} / \mathrm{s}$

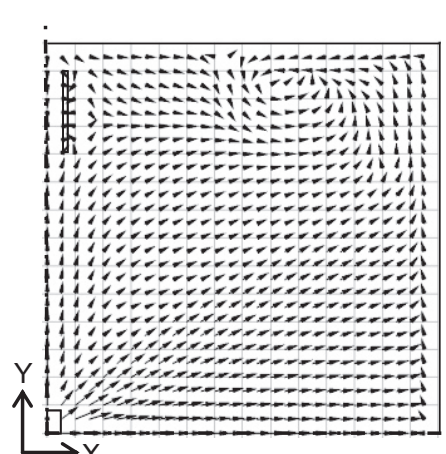

(a) アネモ型吹出口

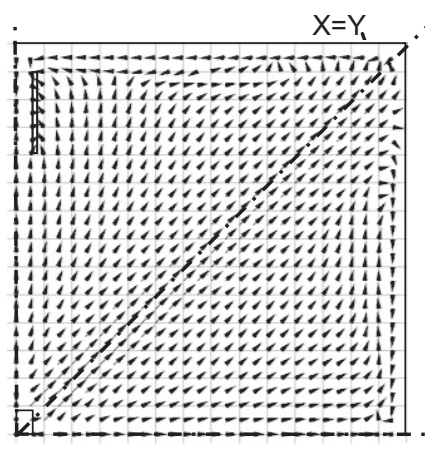

(b) 4 方向吹出口 -350

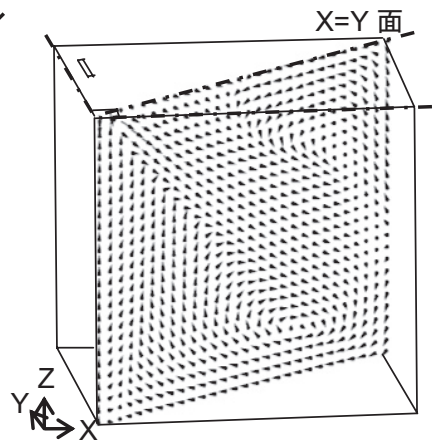

(c) 4 方向吹出口 -240

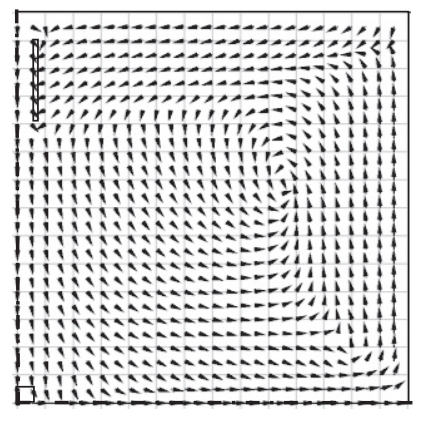

(d) 2 方向吹出口

(2) ベクトル分布 (a)、 (b)、（d) は天井から $10 \mathrm{~mm}$ 下の水平断面 (c) は X=Y の鉛直断面)

図 8 構造格子系 CFD 解析結果 
定しなくても結果には大きな差異が見られず、これらを規定する必 要はないと考えられる。

\section{5. 非等温 CFD 解析によるショートサーキットの検討}

\section{1 ショートサーキット率の概要}

ASHRAE STANDARD 62-198910)において、吹出気流のショート サーキットを『居住域注6)到達することなく、吸込口へ吸込まれる 気流』と考え、『室内に供給する総給気風量とショートサーキットし た風量の割合』をショートサーキット率注7) と呼んでいる。本解析で は、このショートサーキット率を用いて評価する。しかし、CFD 解 析においてショートサーキットした風量を直接算出することはでき ない。そこで粒子追跡法 11),注 8)により、ショートサーキットした粒 子を算出し、それによりショートサーキット率を算出した。

\section{2 解析概要}

解析対象空間はグリッド型システム天井に各吹出口を設置したオ フィス空間を想定する(図 11)。ここでは、ショートサーキットによ る空調・換気効率の影響に着目しており、机等の什器がない単純な モデルとした。解析条件を表 7 に示す。図 11 の天井面の一部に照 明発熱を規定し、床面に OA 機器や人体からの発熱を一様に規定し、 対流・放射連成解析を行う。解析結果からショートサーキット率を 算定する。また、規準化居住域濃度を算出し、ショートサーキット 率との関係などについて検討する。

\section{3 解析結果}

解析結果を図 12 と表 8 に示す。アネモ型吹出口や 4 方向吹出口 -350 から流れる天井付着噴流の一部がショートサーキットしてい る様子が確認できる。表 8 に示すようにショートサーキット率は、 アネモ型吹出口では $46.6 \% 、 4$ 方向吹出口-350 では 39.1\%、4 方向 吹出口- 240 では $8.3 \% 、 2$ 方向吹出口では $0.0 \%$ である。また、規準 化居住域濃度はショートサーキット率が高いほど、高くなる。これ は吹出気流がショートサーキットを形成する傾向が強い場合、居住 域に清浄な吹出気流が到達する割合が小さくなり、また、居住域で 発生した污染質が効率的に除去されにくくなり、污染質の居住域濃 度が高くなるためである。

\section{6 まとめ}

本研究では、システム天井用吹出口のモデリングとしての P.V.法 の有効性を検討し、さらに吹出方向と空調気流のショートサーキッ トの関係について CFD 解析を行い、以下の知見を得た。

(1) 4 種類のシステム天井用吹出口の形状を詳細に非構造格子系 CFD 解析で再現し、吹出気流データを得た。

(2) 非構造格子系 CFD 解析結果と実験結果と比較し、非構造格子 系 CFD 解析結果の妥当性を確認した。

（3）各吹出口を対象に、構造格子系 CFD 解析において P.V.法を適 用し、P.V.法の有効性を確認した。

（4） P.V.法を適用する際には、風速規定面における $\mathrm{k} と \varepsilon の$ 規定の 有無は結果に大きな影響を与えない。

（5）グリッド型システム天井に各吹出口を設置したオフィス空間を 想定し、ショートサーキット率や規準化居住域濃度を算定した。

（6）システム天井に用いられる吹出口は、その種類や形状によって は、ショートサーキットが生じ、室内污染質濃度が上昇する。
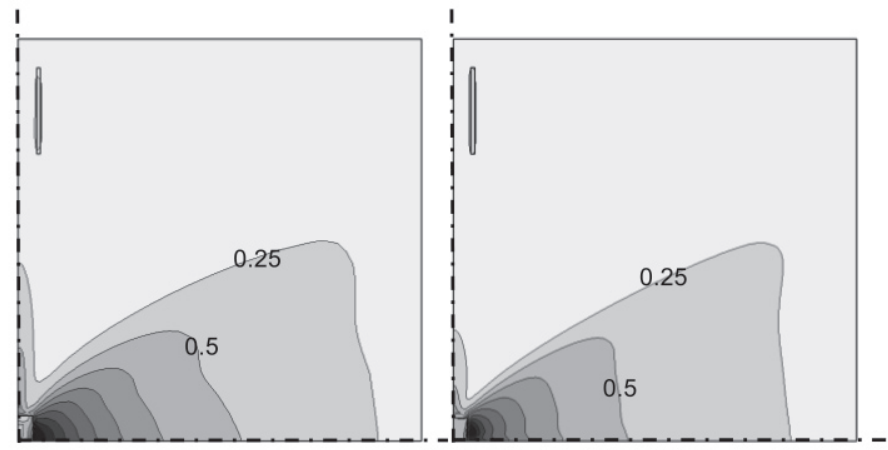

(a) P. V. 法

( $\mathrm{k} 、 \varepsilon$ を与えた場合)

(b) P. V. 法 (k、\&を与えなかった場合)

9 $0.0 \mathrm{~m} / \mathrm{s}$

スカラー風速 $[\mathrm{m} / \mathrm{s}]$ （天井から $10 \mathrm{~mm}$ 下の水平断面、1/4 領域）

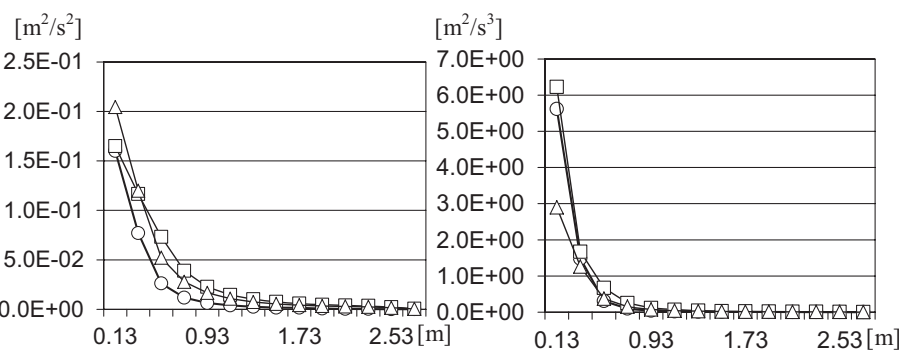

(a) 乱流エネルギー $(\mathrm{k})$

(b) 乱流エネルギーの散逸率 $(\varepsilon)$
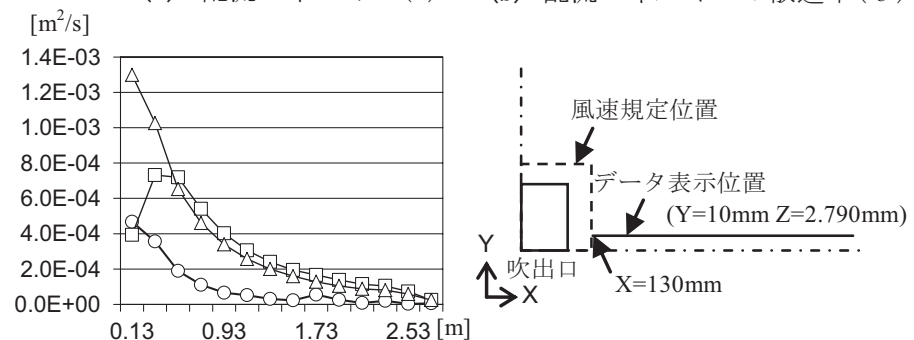

(c) 渦動粘性係数 $(v)$

O 非構造格子系 $\mathrm{CFD}$ 解析 $\square$ P. V. 法 ( $\mathrm{k}$ と $\varepsilon$ を規定) $\triangle$ P. V. 法 $(\mathrm{k}$ と $\varepsilon$ を規定しない)

図 10 風速規定面近傍での $\mathrm{k}$ と $\varepsilon$ 分布

表 7 解析条件 (構造格子系 CFD 解析、非等温)

\begin{tabular}{|c|c|}
\hline 解析領域 & $\begin{array}{l}4.8 \mathrm{~m}(\mathrm{X}) \times 6.0 \mathrm{~m}(\mathrm{Y}) \times 2.7 \mathrm{~m}(\mathrm{Z}) \\
\text { 対称性から全体の } 1 / 4 \text { 領域 }\end{array}$ \\
\hline メッシュ数 & $70(\mathrm{X}) \times 73(\mathrm{Y}) \times 84(\mathrm{Z})=429,240$ \\
\hline 壁面条件 & $\begin{array}{l}\text { 天井・床：一般化対数則 } \\
\text { 鉛直面(対称面) : free-slip 条件 } \\
\text { 温度 : 各表面の熱収支式より算出 } \\
\text { 放射率 : } 0.9 \text { (天井面、床面) } 0.0 \text { (鉛直面) }{ }^{\text {注 9) }}\end{array}$ \\
\hline $\begin{array}{l}\text { 発熱条件 } \\
\text { (1/4 領域) }\end{array}$ & $\begin{array}{l}\text { 人体: } 60 \mathrm{~W} / \text { 人 } \times 1.44 \text { 人 }=86.4 \mathrm{~W}\left(\text { 人員密度 } 0.2 \text { 人 } / \mathrm{m}^{2}\right) \\
\mathrm{PC}: 100 \mathrm{~W} / \text { 台 } \times 1.44 \text { 台 }=144 \mathrm{~W}(1 \text { 人 } 1 \text { 台 }) \\
\text { 照明 }: 20 \mathrm{~W} / \mathrm{m}^{2} \times 7.2 \mathrm{~m}^{2}=144 \mathrm{~W}\end{array}$ \\
\hline $\begin{array}{l}\text { 流入・ } \\
\text { 流出条件 }\end{array}$ & 表 5 参照 \\
\hline その他 & $\begin{array}{l}\text { 吹出風量は、給気温度 } 18.0^{\circ} \mathrm{C} 、 \text { 発熱量、設定温度 } \\
26.0^{\circ} \mathrm{C} \text { (排気温度)とした場合の熱収支式から算出 }\end{array}$ \\
\hline $\begin{array}{l}\text { 規準化居住域 } \\
\text { 濃度 } C_{n}\end{array}$ & $\begin{array}{l}\text { 居住域で污染質を一様発生させて次の式より算出 } \\
C_{n}=C_{\text {room }} / C_{e} \quad\left(C_{\text {room }} \text { : 居住域平均濃度、 } C_{e} \text { : 排気濃度 }\right)\end{array}$ \\
\hline
\end{tabular}




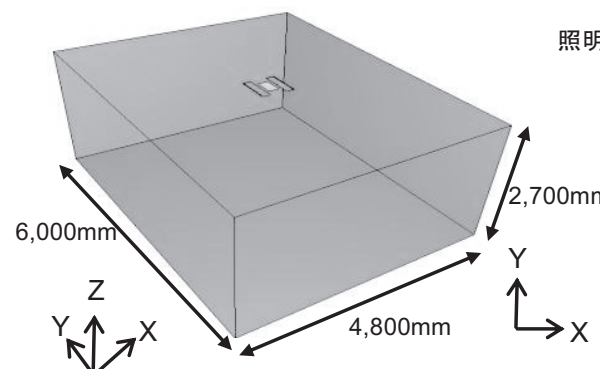

照明 $135 \mathrm{~mm}(\mathrm{X}) \times 600 \mathrm{~mm}(\mathrm{Y})$

(a) 鳥瞰図

$\mathrm{mm}(\mathrm{X}) \times 600 \mathrm{~mm}(\mathrm{Y})$

(b) 吹出口付近の平面図

図 11 解析モデル

表 8 解析結果 (非等温 CFD 解析)

\begin{tabular}{l|c|c|c}
\hline & $\begin{array}{c}\text { ショートサー } \\
\text { キット率[\%] }\end{array}$ & $\begin{array}{c}\text { 規準化居住域 } \\
\text { 濃度[-] }\end{array}$ & $\begin{array}{c}\text { 居住域 } \\
\left.\text { 平均温度 [ }{ }^{\circ} \mathrm{C}\right]\end{array}$ \\
\hline (a) アネモ型吹出口 & 46.6 & 1.67 & 29.7 \\
\hline (b) 4 方向吹出口-350 & 39.1 & 1.45 & 27.7 \\
\hline (c) 4 方向吹出口-240 & 8.3 & 0.98 & 24.9 \\
\hline (d) 2 方向吹出口 & 0.0 & 0.85 & 24.8 \\
\hline
\end{tabular}

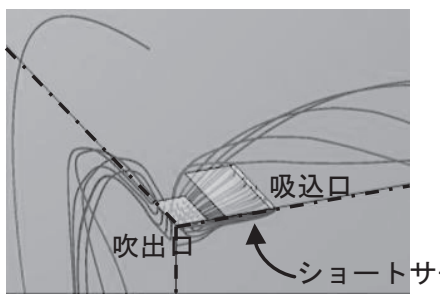

（a）アネモ型吹出口

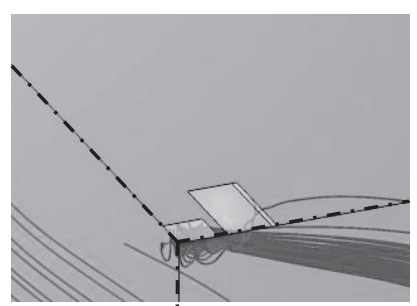

(c) 4 方向吹出口 -240

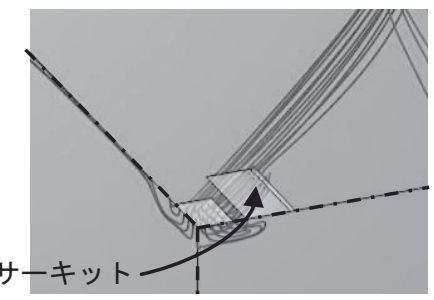

(b) 4 方向吹出口 -350

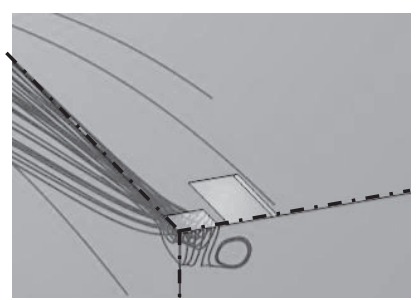

(d) 2 方向吹出口
図 12 吹出気流の流跡線

(非等温 CFD 解析、1/4 領域、室内から室中央を見た状態)

\section{参考文献}

1）近藤, 長澤, 張本, 守屋 : 数值流体解析における空調用天井吹出口のモ デリング手法 等温実大実験と数值シミュレーション(その 1) 日本建 築学会計画系論文集 No.557、pp.65〜 72、2002.7

2) 長澤, 近藤, 張本 : 数值流体解析における空調用天井吹出口のモデリン グ手法 等温実大実験と数值シミュレーション(その 2) 日本建築学会 計画系論文集 No.565、pp.47〜 54、2003.3

3）長澤, 近藤 : 非構造格子系 CFD による簡易 CFD 用吹出気流モデルリン グ作成とその適用 数值流体解析における空調用天井吹出口のモデリ ング手法(その 3) 日本建築学会環境系論文集 No.579、pp.15～20、 2004.5

4) 近藤, 小笠原, 太田, 神村, 徐, 吉田 : 空調制気口の配置に起因するシ ヨートサーキットとミキシングロスに関する CFD 解析 空気調和・衛 生工学会論文集 No.126、pp.27〜30、2007.9

5）太田, 近藤, 阿部, 長澤 : 空調気流のショートサーキットと室内温熱・ 空気環境 日本建築学会大会学術講演梗概集 D-2、pp.691～692、
2008.9

6) 空気調和・衛生工学会規格 SHASE-S102-2003

7) K. Abe, T. Kondo, Y. Nagano: A New Turbulent Model for Predicting Fluid Flow and heat Transfer in Separating and Reattaching Flows-1, Flow Fields Calculations, Int. J. Heat Mass Transfer Vol.37, No.1, pp1467 1481, 1994

8）趙, 太田, 長澤, 近藤 : 空調用吹出口の CFD モデリング手法としての P.V.法の汎用化に関する研究 日本建築学会大会学術講演梗概集 D-2、 pp.707〜 708、2009.8

9）趙, 太田, 長澤, 近藤 : システム天井用吹出口の CFD モデリング手法 としての P.V.法とその応用 空気調和・衛生工学会大会学術講演論文集、 pp.2507 2510、2010.9

10）吉野, 内海：ASHRAE 規格 62-1989 “室内空気質を正しく維持するた めの換気に関する規格”(その 2)、空気調和・衛生工学、1993.5

11）太田，近藤：粒子追跡法による局所換気装置の直接捕集率(DCE)の 算定 空気調和・衛生工学会大会学術講演論文集、pp. 1111 1114、 2009.9

注

注1）乱流統計量の流入境界条件 $\left(k_{i n}\right.$ と $\left.\varepsilon_{i n}\right)$ は下記から求めた。

$$
\begin{aligned}
& k_{i n}=U_{i n}{ }^{2} \div 100 \\
& \varepsilon_{i n}=0.09^{3 / 4} \times k_{i n}{ }^{3 / 2} \div(0.07 \times D) \\
& D: \text { 流入境界面の短辺 }[\mathrm{m}]
\end{aligned}
$$

注2） 3 次元超音波風速計の測定範囲は直径 $30 \mathrm{~mm}$ の球状であるため、これ と比較する非構造格子系 CFD 解析結果は以下のようにした。すなわち、 天井面下 $10 \mathrm{~mm} \sim 40 \mathrm{~mm}$ の $1 \mathrm{~mm}$ 間隔の 30 個の解析結果 $(U, V, W)$ を平 均したものを用いて図 5 を作成した。

注3） $150 \mathrm{~mm}(\mathrm{X}) \times 150 \mathrm{~mm}(\mathrm{Y})$ は主流方向規定面の仮想ボックスサイズを示す。 $\mathrm{Z}$ 方向規定面の外側の仮想ボックスサイズは $165 \mathrm{~mm}(\mathrm{X}) \times 165 \mathrm{~mm}(\mathrm{Y})$ で ある。

注4） 4 方向吹出口-240 以外のケースについても $\mathrm{Z}$ 方向成分の風速を規定し た計算を行ったが、結果にはほとんど差異は見られなかった。風速の 規定方法はできるだけ簡易であるのが望ましいと考え、4 方向吹出口 -240 以外のケースについては Z 方向成分の風速を規定していない結果 を本研究では示した。

注5）非構造格子系 CFD 解析から得られた $\mathrm{k}$ とををえて P.V.法を適用した 結果と非構造格子系 CFD 解析の結果を比較すると差異が見られる。こ れは主に乱流モデルと境界条件の影響であると考えられる。すなわち、 非構造格子系 CFD 解析では低 Re 数型 $\mathrm{k}^{-} \varepsilon$ model を用い、壁面での気 流の境界条件は no-slip としているのに対し、P.V.法では標準 $\mathrm{k}^{-} \varepsilon$ model を用い、壁面での気流の境界条件は対数則としている。

注6）本研究では居住域の範囲は床から上 $1.8 \mathrm{~m}$ までとした。

注7） ショートサーキット率の算定方法を補図 1(次頁)に示す。

注8）粒子追跡法の概要を下記に示す。粒子の速度 $u_{p}$ は(2)式の粒子の運動方 程式から得られる。粒子の運動方程式では流体から受ける力は抗力の みとし、流体は粒子から反作用の力を受けないものとする。また、 Stokes 数が十分小さくなるように粒径 $D_{P}$ を極めて小さく設定し $\left(D_{P}\right.$ $=1.0 \mathrm{E}-20 \mathrm{~m}$ )、粒子は流体の移流にパッシブに挙動するものとした。空 気の速度 $u_{f}$ は、CFD 解析で求めた空気の速度の平均成分 $U_{f}$ に変動速 度成分 $u_{f}^{\prime}$ を加えた速度として(1)式で表される。変動速度成分 $u_{f}^{\prime}$ は、 平均值が 0 であり、標準偏差 $\sigma$ が(3)式となるような正規乱数を発生さ せることにより与えることができる。文献 11 と同様に粒子の発生個数 を検討した結果、10,000 個で充分であったため、本研究では発生個数 を10,000 個とした。

$$
\begin{aligned}
& u_{f}=U_{f}+u_{f}^{\prime} \\
& m_{p} \frac{d u_{p}}{d t}=\frac{1}{8} C_{D} \pi D_{P}{ }^{2}\left|u_{f}-u_{p}\right|\left(u_{f}-u_{p}\right) \\
& \sigma=\sqrt{\frac{2}{3} k}
\end{aligned}
$$


注9）解析モデルでは鉛直面が対称面であり、この面における気流の境界条 件は free-slip とし、温度の境界条件は断熱(free-slip)としている。また、 放射熱伝達については完全鏡面反射とし、放射率は 0.0 を与えた。

\begin{tabular}{lll} 
記号表 & \\
\hline$U_{\text {in }}$ & $:$ 流入速度 $[\mathrm{m} / \mathrm{s}]$ \\
$k_{\text {in }}$ & $:$ 乱流エネルギー $k$ の流入条件 $\left[\mathrm{m}^{2} / \mathrm{s}^{2}\right]$ \\
$\varepsilon_{\text {in }}$ & $:$ 乱流エネルギーの散逸率 $\varepsilon$ 流入条件 $\left[\mathrm{m}^{2} / \mathrm{s}^{3}\right]$ \\
$Q_{\text {in }}$ & $:$ 流入風量 $\left[\mathrm{m}^{3} / \mathrm{h}\right]$ \\
$C_{n}$ & $:$ 規準化居住域濃度 $[-]$ \\
$u_{p}$ & $:$ 粒子の速度 $[\mathrm{m} / \mathrm{s}]$ \\
$u_{f}$ & $:$ 空気の速度 $[\mathrm{m} / \mathrm{s}]$ \\
$U_{f}$ & $:$ 空気の速度の平均成分 $[\mathrm{m} / \mathrm{s}]$ \\
$u_{f}^{\prime}$ & $:$ 空気の速度の変動成分 $[\mathrm{m} / \mathrm{s}]$ \\
$m_{p}$ & $:$ 粒子の質量 $[\mathrm{kg}]$ \\
$C_{D}$ & $:$ 抵抗係数 $[$ 一 $]\left(C_{D}=1.0\right)$ \\
$D_{P}$ & $:$ 粒径 $[\mathrm{m}]$ \\
\hline
\end{tabular}

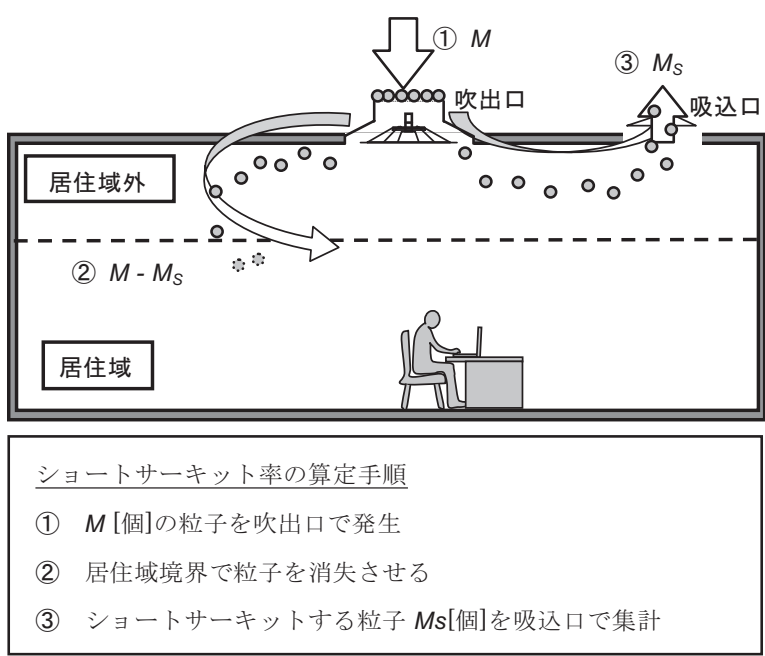

補図 1 ショートサーキット率の算定方法 